\title{
Is there a Real Chance to Adopt the CCCTB without UK Participation in the EU? ${ }^{1}$
}

\author{
Danuše NERUDOVÁ* - Veronika SOLILOVÁ* - Marek LITZMAN**
}

\begin{abstract}
The European Commission re-launched its proposal on the Common Consolidated Corporate Tax Base (CCCTB) in Europe in October 2016. The CCCTB aims to help ensure a fair and efficient corporate tax system in the European Union as a tool to fight tax evasion and tax fraud. Moreover, the CCCTB could be intended to be used as a new resource for the EU budget, as the EU budget requires reassessment after Brexit. Although the outcome of the Brexit process was uncertain for a long time, the UK left the EU on 31 January 2020. The objective of this paper is to research the impact of the introduction of the CCCTB on the EU's economic environment in the post-Brexit period. The research reveals that the overall tax base under the CCCTB in the post-Brexit period would decline by $5.34 \%$ in comparison with the current tax base. Through a dynamic approach, we find that the CCCTB could increase the tax base by between $3.33 \%$ and $22.42 \%$, depending on the behavioural effects induced by the implementation of the proposal.
\end{abstract}

Keywords: Common Consolidated Corporate Tax Base, large entities, small and medium-sized enterprises, European Union, Brexit

JEL Classification: H25, K22

DOI: https://doi.org/10.31577/ekoncas.2021.06.02

\section{Introduction}

Currently, companies operating in the EU-27 face 27 different corporate taxation systems, which have many loopholes that are often used by multinational enterprises (hereinafter MNEs) for aggressive tax planning, leading to base erosion

* Danuše NERUdOVÁ - Veronika SOLILOVÁ, Mendel University in Brno, Faculty of Business and Economics, Department of Accounting and Taxes, Zemědělská 1, 61300 Brno, Czech Republic; e-mail: d.nerudova@seznam.cz; ritve@email.cz

** Marek LITZMAN, Mendel University in Brno, Faculty of Business and Economics, Department of Economics, Zemědelská 1, 61300 Brno, Czech Republic; e-mail: marek@litzman.cz

${ }^{1}$ The paper present the results of the FairTax project funded by the European Union's Horizon 2020 research and innovation programme 2014 - 2018, grant agreement No. FairTax 649439. 
and profit shifting in the European Union. The European Commission has always strived to structurally harmonise corporate taxation; lastly reconsidered the previous proposal of the Common Consolidated Corporate Tax Base (European Commission, 2011) and to relaunch the project. The European Commission (2016a; 2016b) published two directive proposals, the Proposal on the Council Directive on a Common Corporate Tax Base (hereinafter the CCTB directive) and the Proposal on the Council Directive on a Common Consolidated Corporate Tax Base (hereinafter the CCCTB directive), in October 2016. In comparison with the previous proposal, the CCCTB is understood to be a tool to fight tax evasion and tax fraud and is able to ensure the link between taxation and the places where profits are generated and value is created to prevent market distortion. ${ }^{2}$ Both of the above-mentioned directives are mandatory for all multinational groups with consolidated revenue of at least EUR 750 million. With respect to the withdrawal of the United Kingdom from the European Union (hereinafter Brexit), both proposals were published after the Brexit referendum in June 2016, when $52 \%$ of those voting in the referendum supported withdrawal.

However, the directive proposals and related impact assessments did not take into account the impact of Brexit. Although whether Brexit would actually occur was uncertain for a long time, the UK left the EU on 31 January 2020 and a transition period ended on 31 December 2020.

Currently, legislative proposals fall under the EU's consultation procedure. To ensure the elimination of profit shifting and tax base erosion before the $\mathrm{C}(\mathrm{C}) \mathrm{CTB}$ approval, the European Commission approved rules ${ }^{3}$ against tax avoidance practices that directly affect the functioning of the Internal market known as ATAD Directive, in 2016. In October 2017, the Committee on Legal Affairs called on the Committee on Economic and Monetary Affairs (ECON) to take into account the amendment of the threshold for tax consolidation in case of the CCCTB proposal. A similar opinion had also been given by the European Trade Union Confederation (ETUC). In the European Parliament, both tax proposals were assigned to the ECON, with a report on the subject released on 21 February 2018. Specifically, the report suggests amending the proposal of the $2016 \mathrm{C}(\mathrm{C}) \mathrm{CTB}$ directive in regards to the threshold for the mandatory application of the directive, reducing the threshold from EUR 750 million to zero over a maximum period of seven years (European Parliament, 2018). Furthermore, the report takes into account the digital change in the business environment, as the digitalisation of the world economy, e-commerce and new business models offer significant opportunities for

\footnotetext{
${ }^{2}$ The proposals present interest limitation rules based on firms' EBITDA and rules for hybrid mismatches.

${ }^{3}$ It covers the interest limitation rule, GAARs, the CFC rules and the hybrid mismatches rule.
} 
businesses. As a result, the formulary apportionment for the consolidated tax base comprises four equally weighted factors, i.e., collection and use of personal data of online platforms and services users (hereinafter 'the data factor'). Last, taking into account the future international economic environment in the post-Brexit period, it is suggested that both proposals be adopted in one step instead of the previously announced two-step approach. The European Parliament adopted its opinion in a plenary session on 15 March 2018, and the proposal is now in the hands of the Council. To date, there is no published position of the Council.

Nevertheless that the $\mathrm{C}(\mathrm{C}) \mathrm{CTB}$ proposals have been waiting for the negotiation four years, they are still on the table via Package for fair and simple taxation and the Action Plan for Business Taxation for the 21st century. Therefore, the question is whether there is a real chance of adopting the CCCTB and whether the CCCTB would be able to generate sufficient resources in the post-Brexit landscape

The objective of this paper is to research the impacts of the introduction of unitary taxation in the form of the CССТВ on the economic environment in the European Union after Brexit. Moreover, our semi-dynamic model also takes into account the behaviour of SMEs and large entities that can enter voluntarily into the proposed corporate tax system to receive some advantages such as lower tax liability, lower compliance costs of taxation, cross-border loss offsetting and others, and a case in which all eligible entities enter the CCCTB system (i.e. in case of the zero threshold of mandatory application).

The paper is organised as follows. In the first section, we present current knowledge on the CCCTB. In the second section, we describe the data and model used for the empirical methodology. In the third section of this paper, we present and discuss the results obtained in comparison with the current research on the CCCTB. In the last section, we present our concluding remarks.

\section{Literature Review}

The existing literature on the CCCTB can be categorised into six main streams. The first is concentrated on the concept of the CCCTB in general and studies the impact of its implementation in national tax systems; this stream includes works such as Hulya and Hodžić (2017), Röder (2012), Nielsen, Raimondos-Møller and Schjelderup (2010), Bettendorf et al. (2009), Dahle and Bäumer (2009), Andersson (2007), Barenfeld (2007) and Riedel and Runkel (2007). The second stream focuses mainly on the allocation formula factors with respect to the prediction of corporate income, and is represented by studies such as Mintz (2008) and Eberhartinger and Petutschning (2014), or with respect to the factors' explanatory power, Hines (2008), Roggeman et al. (2012), Cobham and Loretz (2014), 
Krchnivá and Nerudová (2015) and Hundsdoerfer and Wagner (2020). The third stream of research includes studies on the impacts of the introduction of the CCCTB on the tax revenues of EU Member States, such as Fuest, Hemmelgarn and Ramb (2007), Brochner et al. (2007), Oestreicher and Koch (2011), Oestreicher, Keser and Kimpel (2013), Devereux and Loretz (2008), van der Horst, Bettendorf and Rojas-Romagosa (2007), Bettendorf et al. (2009), Cline et al. (2010), Cobham et al. (2017), Solilová and Nerudová (2018), Nerudová and Solilová (2019) and Hentze (2019). The fourth stream represents studies that do not focus on the impact on the EU but rather on individual states, such as Skjerpe (2012) for Norway, Pirvu, Banica and Hagiu (2011) for Romania, Scerri (2009) for Malta, Domonkos et al. (2013) and Nerudová and Solilová (2017b) for the Slovak Republic, Nerudová and Solilová (2015a) and Nerudová and Solilová (2015b) for the Czech Republic, and Sampaio Cândido (2016) for Portugal. The five stream of research on the CCCTB is concentrated on the concept of the CCCTB and the prediction of tax revenues for the purpose of a new taxbased own resources to finance the EU budget; this stream includes studies such as Schratzenstaller and Krenek (2019) and Nerudová, Solilová and Dobranschi (2016). The last stream of research on the CCCTB is focused on the issue how the CCCTB is able to reach fair taxation together with the elimination of profit shifting and tax base erosion, such as Valenduc (2019), Hentze (2019), Eichfelder, Hechtner and Hundsdoerfer (2018), de Wilde (2017), Ortmann and Sureth-Sloane (2016), Keser, Kimpel and Oestreicher (2016), Kiesewetter, Steigenberger and Stier (2018) and Martini, Niemann and Simons (2012).

Even though the research on the CССТВ is very extensive, to date, there is no published research on the CCCTB assessing the post-Brexit landscape. In the context of the lack of impact assessments giving consideration to Brexit, we would like to fill this gap and research the new tax-base sharing mechanism under the CCCTB in the post-Brexit landscape, including changes in the behaviour of entities that can enter the CCCTB system voluntarily and taking into account a decrease of threshold to zero.

\section{Data and Methodology}

The methodological approach in this article is based on micro data. We employ data on the eligible companies ${ }^{4}$ from the Amadeus database for NACE industry codes A-S $\mathrm{S}^{5}$ (except NACE code K) and from the Bankscope database for NACE

\footnotetext{
${ }^{4}$ Based on the Article 3 of the CССТВ proposal, an eligible company is a company which fulfils a two-layer cumulative condition for the consolidation and group taxation scheme, i.e., at least $50.01 \%$ of ownership rights and more than $75 \%$ of voting rights.
} 
code $\mathrm{K}$ (financial sector), as it is one of the special industries for which the adjusted allocation formula should be applied.

To research the tax-base sharing mechanism under the CCCTB with different thresholds ${ }^{6}$ and the changes in behaviour of the entities falling under the researched threshold within the economic environment of the post-Brexit period, we start with the model applied by Nerudová et al. (2016), which is further developed to capture the voluntary element suggested by the European Parliament in its report in March 2018. In comparison with Nerudová et al. (2016), the model covers the changes in behaviour of companies not obligated to enter into the CCCTB system in reaction to the introduction of this system. Specifically, we consider the changes in behaviour of SMEs ${ }^{7}$ and large entities ${ }^{8}$ that do not reach the threshold of EUR 750 million of consolidated turnover. In the case of the zero threshold, all eligible entities have to enter the C(C)CTB system. Further, in comparison with Nerudová and Solilová (2017a), our model does not include corporate entities with tax residency in the UK and UK-based subsidiaries of corporate entities with tax residency in the EU, as we focus on the post-Brexit landscape.

To determine the volume of the tax base under the CCCTB system, we apply the allocation formula (1) for NACE industry codes A-S to the tax bases of the qualified group of entities except for NACE industry code $\mathrm{K}$, for which the special-adjusted allocation formula is used, similarly as in previous research. Although the latest version of the CCCTB proposal covers the allocation formula with four equally weighted factors, i.e., tangible fixed assets, sales, payroll and data factor, our study takes into account only 3 of them, without the data factor. The main reason is the unavailability of data for the calculation of the new added factor.

The applied allocation formula under the CCCTB system for the purposes of our study is as follows:

$$
\text { ShareX }=\left(\frac{1}{3} \frac{S^{A}}{S^{\text {group }}}+\frac{1}{3}\left(\frac{1}{2} \frac{P^{A}}{P^{\text {Group }}}+\frac{1}{2} \frac{E^{A}}{E^{\text {Group }}}\right)+\frac{1}{3} \frac{A^{A}}{A^{\text {Group }}}\right) * C C C T B
$$

\footnotetext{
${ }^{5}$ For these classification of NACE codes, see $<$ https://ec.europa.eu/competition/mergers/cases/index/nace_all.html>.

${ }^{6}$ For the purposes of this study, we use the threshold of EUR 750 million (the threshold for the mandatory application of the $\mathrm{C}(\mathrm{C}) \mathrm{CTB}$ system) and zero (a suggested threshold), i.e., all eligible firms must enter the $\mathrm{C}(\mathrm{C}) \mathrm{CTB}$ system.

${ }^{7}$ Entities recording operating revenues higher than EUR 1 million and total assets higher than EUR 2 million and having more than 15 employees.

${ }^{8}$ Entities recording operating revenue higher than EUR 10 million and total assets higher than EUR 20 million and having more than 150 employees.
} 
where

$S$ - represents sales, which are based on the sales of goods and services;

$P$ - represents payroll, which includes the cost of salaries, wages, bonuses and all other employee compensation, including related pension and social security costs borne by the employer;

$E$ - represents the number of employees, which are considered part of the group that is paid remuneration, unless they are under the control of a different group member, in which case they are considered part of that group; employees are included if they are employed for at least three uninterrupted months; and

$A$ - represents assets, which include all fixed tangible assets, including buildings, airplanes and machinery that is owned, rented, or leased by a group member.

According to the proposals, the special-adjusted allocation formula is applied for industry sector $\mathrm{K}$ as regards to financial institutions and insurance undertakings.

The impact of CCCTB implementation on the economic environment in the post-Brexit landscape is determined as a comparison with the current situation regarding the corporate tax base allocation in each Member State if the current four taxation regimes are applied, i.e., the full consolidation, pooling, intra-group loss transfer and no group taxation ${ }^{9}$ schemes.

\section{Motivations and Limitations}

As microenterprises, SMEs and large entities, that do not meet the threshold of EUR 750 million are exempted from the obligatory application of the CCCTB system, these entities (groups) can still opt to participate in the CCCTB system voluntarily. Therefore, we formulate the following motivations for an MNE to enter the system voluntarily:

- lower compliance costs of taxation through the unified system of tax base construction and the one-shop-stop approach; based on the common rules for corporate tax base construction, SMEs and large entities would not have to face the 27 different tax systems that result in high taxation compliance costs;

- cross-border loss offsetting;

- lower tax liability;

- a super-deduction for R\&D, notably for SMEs and start-up companies;

- fair tax competition (i.e., the situation in which all market subjects have the same information about the effective tax rate);

- elimination of tax obstacles to mergers and acquisitions mainly in the areas of capital profit taxation; and

- elimination of transfer pricing issues.

${ }^{9}$ It should be highlighted that group taxation is not available in Belgium, Bulgaria, Croatia, Czech Republic, Greece, Hungary, Slovak Republic, Slovenia, Estonia, Romania, Latvia and Lithuania. 
The main motivation for entities to enter the CCCTB system represents the lower tax burden for the whole group. Therefore, our dataset is divided into two groups. First, the entities with a lower tax burden in the group are identified, and the effect of their entrance into the CCCTB system is researched (for the SME and large entities). The second group of entities represents the entities that would encounter a higher tax burden in the group after entrance into the CCCTB system. However, in this group of entities, other motivations to enter the system may still exist (see above), which could ultimately outweigh the higher tax burden factor in the group. Moreover, we researched following situation:

1. situation in which only entities meeting the threshold of EUR 750 million enter the system;

2. situation in which SMEs and large entities not meeting the threshold enter the system as a result of behavioural change; and

3. situation in which all eligible entities enter the system via a zero threshold of mandatory application.

The structure of the semi-dynamic model enables (in case the second situation) research on the range of the impacts of the CCСТВ implementation; that is, it allows us to quantify:

- the minimum effect of the tax-base sharing mechanism under the CCCTB in the post-Brexit landscape (the situation in which the results account for entities that would be motivated to enter by the lower overall tax burden of the group) and

- the maximum effect or total effect (the situation in which the results account for entities that would enter the system even when the tax burden of the group is not lower, because other features connected with the system are more attractive for them; consequently, the total effect captures both effects - min and max).

It is also necessary to mention the limitations of the study. First, we assume that the overall corporate tax base volume in the EU-27 remains unchanged after the implementation of the CCCTB. Second, we assume profit before tax as the tax base of the entity to determine the CCCTB and current corporate tax base. Third, as the model used for the simulation is based on one-year data, the offsetting of previous losses, tax incentives and other preferential tax regimes are not considered during the determination of current corporate tax base allocation. Fourth, the sales factor used for the allocation formula is based on the state of the sales source, in contrast to the CCCTB proposal based on sales by destination; that is, sales of goods would be included in the sales factor of the group member located in the Member State where the dispatch or transport of the goods to the person acquiring them ends. Sales by destination cannot be used due to the lack of databases collecting this kind of data. Similarly, the new proposed factor in the formula - the data factor - cannot be used. 


\section{Results and Discussion}

From an economic perspective, there are many studies predicting negative impacts of Brexit on the UK economy (Boulanger and Philippidis, 2015; Ottaviano et al., 2015; Felbermayer et al., 2017 and others), specifically, UK welfare losses ranging between $0.67 \%$ and $3.09 \%$ of UK per capita real income compared to EU-27 losses of $0.25-0.11 \%$. Moreover, most economists and the UK Treasury also highlight the strong negative effect on trade (HM Government, 2016; Boulanger and Philippidis, 2015 and others). How Brexit will affect the current and future situation in the area of corporate taxation in the EU is also being questioned.

In connection with Brexit, it must be noted that both the highest cross-border losses and the highest number of eligible entities under the CCCTB system are situated in the United Kingdom. Almost $44 \%$ of the current corporate tax base volume of all eligible companies is situated in the United Kingdom. Similarly, more than $40 \%$ of the whole CCCTB is situated in the United Kingdom. Therefore, it could be assumed that Brexit will have a significant impact on the mechanism for tax-base sharing across the EU Member States under the CCCTB system (Nerudová and Solilová, 2017a).

In the post-Brexit economic environment, our research identifies (without considering any threshold) 52,355 eligible parent companies operating in the United Kingdom with 157,625 subsidiaries, of which 142,045 are situated in the UK and the rest (i.e., 15,580) in the EU. Those groups (except for the subsidiaries in the EU) cannot enter the CCCTB system as a result of Brexit. Furthermore, the research identifies 5,179 eligible parent companies operating in the EU with 19,113 subsidiaries situated in the UK. Like the previous groups, the UK-based subsidiaries of EU-based parent companies are no longer within the group of eligible companies for our modelling of the tax-base sharing mechanism under the CCCTB. Furthermore, the highest shares of those entities (parent companies) are in Germany, Ireland, Italy and the Netherlands.

Regarding the volume of the tax base that cannot be considered for inclusion in the tax-base sharing mechanism under the CCCTB, UK-based subsidiaries generate a tax base of EUR 360,000 million, and only EUR 47,300 million, i.e., $13 \%$, is related to the EU-based parent company. The EU-based subsidiaries of the UK-based parent companies generate a tax base of EUR 49,900 million, which we consider in our modelling of the tax-base sharing mechanism.

Eligible entities meeting the threshold of EUR 750 million (mandatory application) and all eligible entities enter the system (zero threshold)

In the post-Brexit economic environment, our research identified 95,046 entities (specifically 1,676 groups) within the EU-27 that would obligatorily enter the CCCTB system because they exceed the threshold of EUR 750 million in 
consolidated turnover. The research reveals that the implementation of the consolidation element together with the tax-base sharing mechanism in the form of allocation formula (1) would generate a tax base of EUR 442.18 billion in comparison with the current tax base of EUR 467.12 billion in the entire EU-27 (i.e., a decrease of 5.34\%). If the threshold of mandatory application decreases to zero, then the research identified 3,855,814 eligible entities and 1,691,333 groups that would generate a tax base of EUR 557.55 billion under the CCCTB in comparison with the current tax base of EUR 600.55 billion in the EU-27 (i.e., a decrease of 7.16\%). Although the number of eligible entities together with the number of groups would significantly increase after the change of the threshold related to the mandatory entering of the CCCTB system, this action would not be reflected in the same proportion in the size of the tax base. The tax base would increase by $26 \%$ (EUR 115.37 billion; for details see Table 1).

Table 1

Tax-base Sharing Mechanism under the CCCTB for the EU-27 in Million EUR in the Post-Brexit Period

\begin{tabular}{|c|c|c|c|c|c|c|}
\hline Country & $\begin{array}{c}\text { Current TB } \\
\text { Threshold } \\
750 \mathrm{mil} \\
\end{array}$ & $\begin{array}{c}\text { CCCTB } \\
\text { Threshold } \\
750 \text { mil } \\
\end{array}$ & $\%$ change & $\begin{array}{c}\text { Current TB } \\
\text { Zero Threshold }\end{array}$ & $\begin{array}{c}\text { CCCTB } \\
\text { Zero Threshold }\end{array}$ & $\%$ change \\
\hline FR & $93,239.4$ & $99,877.4$ & 7 & $102,960.1$ & $109,372.7$ & 6 \\
\hline NL & $81,841.6$ & $62,960.2$ & -23 & $88,786.3$ & $67,534.7$ & -24 \\
\hline DE & $70,601.9$ & $75,684.7$ & 7 & $79,213.0$ & $84,838.7$ & 7 \\
\hline ES & $40,182.5$ & $36,551.5$ & -9 & $51,442.3$ & $44,375.5$ & -14 \\
\hline IT & $34,596.9$ & $42,840.2$ & 24 & $70,184.6$ & $76,545.5$ & 9 \\
\hline SE & $28,614.7$ & $24,750.1$ & -14 & $39,179.3$ & $33,648.6$ & -14 \\
\hline $\mathrm{BE}$ & $26,385.6$ & $18,752.9$ & -29 & $31,524.0$ & $23,083.4$ & -27 \\
\hline DK & $14,988.8$ & $14,053.5$ & -6 & $19,819.0$ & $18,856.9$ & -5 \\
\hline AT & $10,760.5$ & $9,428.2$ & -12 & $13,662.3$ & $12,199.8$ & -11 \\
\hline IE & $10,020.8$ & $6,889.6$ & -31 & $13,734.3$ & $9,706.5$ & -29 \\
\hline FI & $9,796.6$ & $7,038.7$ & -28 & $11,846.3$ & $9,008.7$ & -24 \\
\hline LU & $9,734.3$ & $2,919.9$ & -70 & $12,201.3$ & $4,666.0$ & -62 \\
\hline $\mathrm{CZ}$ & $8,508.0$ & $7,094.9$ & -17 & $11,873.5$ & $10,135.3$ & -15 \\
\hline PL & $8,354.6$ & $8,846.2$ & 6 & $13,055.7$ & $12,435.8$ & -5 \\
\hline PT & $5,537.1$ & $5,157.2$ & -7 & $9,020.4$ & $7,793.4$ & -14 \\
\hline $\mathrm{RO}$ & $3,145.7$ & $5,435.9$ & 73 & $9,323.6$ & $10,809.2$ & 16 \\
\hline SK & $3,111.9$ & $2,787.8$ & -10 & $4,454.6$ & $3,876.0$ & -13 \\
\hline $\mathrm{HU}$ & $2,779.9$ & $4,744.7$ & 71 & $3,033.1$ & $5,023.9$ & 66 \\
\hline HR & $1,490.4$ & $2,121.5$ & 42 & $2,821.6$ & $3,338.9$ & 18 \\
\hline EL & $1,052.6$ & $1,020.6$ & -3 & $2,419.7$ & $1,126.5$ & -53 \\
\hline $\mathrm{EE}$ & 683.7 & 953.2 & 39 & $1,727.9$ & $1,811.7$ & 5 \\
\hline BG & 676.0 & 699.1 & 3 & $3,715.9$ & $3,214.3$ & -13 \\
\hline LT & 483.2 & 596.4 & 23 & $1,452.9$ & 990.7 & -32 \\
\hline LV & 267.5 & 705.5 & 164 & $1,874.2$ & $2,176.0$ & 16 \\
\hline SI & 165.5 & 238.6 & 44 & 731.1 & 793.4 & 9 \\
\hline MT & 56.1 & 12.9 & -77 & 171.6 & 76.8 & -55 \\
\hline $\mathrm{CY}$ & 42.0 & 15.5 & -63 & 324.1 & 110.1 & -66 \\
\hline Total & $467,117.8$ & $442,177.5$ & 7 & $600,552.7$ & $557,549.7$ & \\
\hline Change (\%) & \multicolumn{3}{|c|}{-5.34} & \multicolumn{3}{|c|}{-7.16} \\
\hline
\end{tabular}

Note: TB - tax base.

Source: Amadeus and Bankscope databases, own calculations. 
This is mainly due to the short-term effect of cross-border loss offsetting, ${ }^{10}$ which is available in the CCCTB system, and many groups of SMEs newly obliged to enter the CCCTB system generating very small tax bases. It is obvious that the highest proportion of the tax base under the CCCTB is generated by large entities that pass the threshold of EUR 750 million in consolidated turnover. From the fiscal point of view, the change of the threshold would not mean a significant increase in CCCTB system yield. This finding was also highlighted in the study by Nerudová and Solilová (2019) in the case of the EU-28. However, before the final consideration of the CCCTB, other aspects of the CCCTB should be considered. The CCCTB system would improve the Internal market and ensure a fair and efficient corporate tax system in the whole EU.

As shown in Scheme 1a and 1b, the highest negative change in the tax base (red colour in the scheme) would be generated in Malta, Luxemburg and Cyprus, and the highest positive change in the tax base (green colour in the scheme) would be generated in Latvia, Hungary and Romania. Furthermore, if all eligible entities are considered in the zero threshold case, Greece (with the highest negative change in the tax base) and Croatia (with the highest positive change in the tax base) would be identified in addition to the above-mentioned countries. Nevertheless, the relative change in the tax base would be large, at between $-76.92 \%$ and $163.67 \%$ across EU Member States, with an overall negative change of 5.34\% in the EU-27. In the case of a zero threshold, the relative change in the tax base would be more balanced, at between $-66.04 \%$ and $65.64 \%$ across EU Member States, with an overall negative change of $7.16 \%$ in the EU-27. Moreover, it is obvious that the CCCTB system with the EUR 750 million thresholds would have the most positive impact on the post-communist countries, in which no group-MNE taxation schemes are currently available. Furthermore, it is proven that countries with the highest negative change in the tax base currently do not tax corporate profits in relation to created value and places where this value is created.

If the results are compared with the studies by Nerudová and Solilová (2017a; 2019), the presented results taking into account the post-Brexit landscape reveal a decrease in the tax base that is slightly higher than in the aforementioned studies but with only a marginal change (max up to one percent change). Moreover, the number of countries with a positive change in the tax base decreases from 19 to 12, comparing the results published in studies by Nerudová and Solilová (2017a; 2019). It is obvious, that the non-participation of the UK in the CCCTB system is having more negative effect (for more details see Table 1).

\footnotetext{
${ }^{10}$ It should be note, the СССТВ proposal offers the cross-border loss-offsetting, but with recapture approach i.e. that loss-offsetting is only short-term and after set period the CCCTB is increased by the corresponding amount.
} 
Sche me 1a

The Change in the Tax Base after CCCTB Implementation in the Dataset of Entities Obligatorily Entering the CCCTB System (EUR 750 Million Thresholds) in the Post-Brexit Period

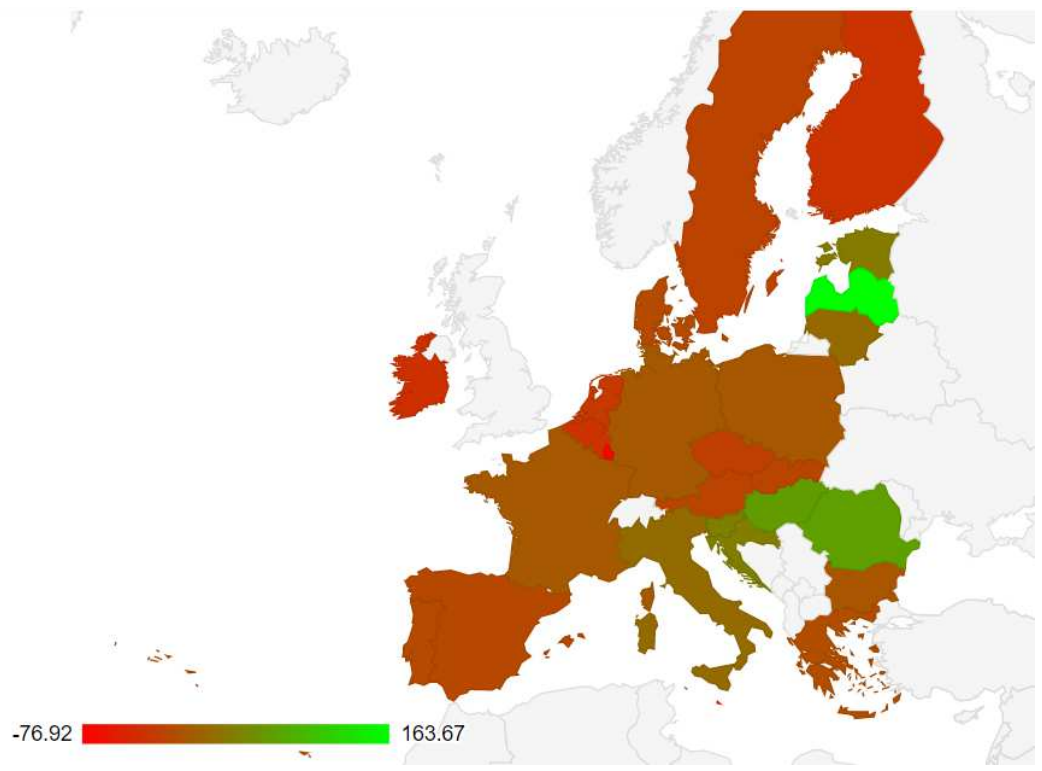

Scheme $1 b$

The Change in the Tax Base after CCCTB Implementation in the Dataset of Entities Obligatorily Entering the CCCTB System (Zero Threshold) in the Post-Brexit Period

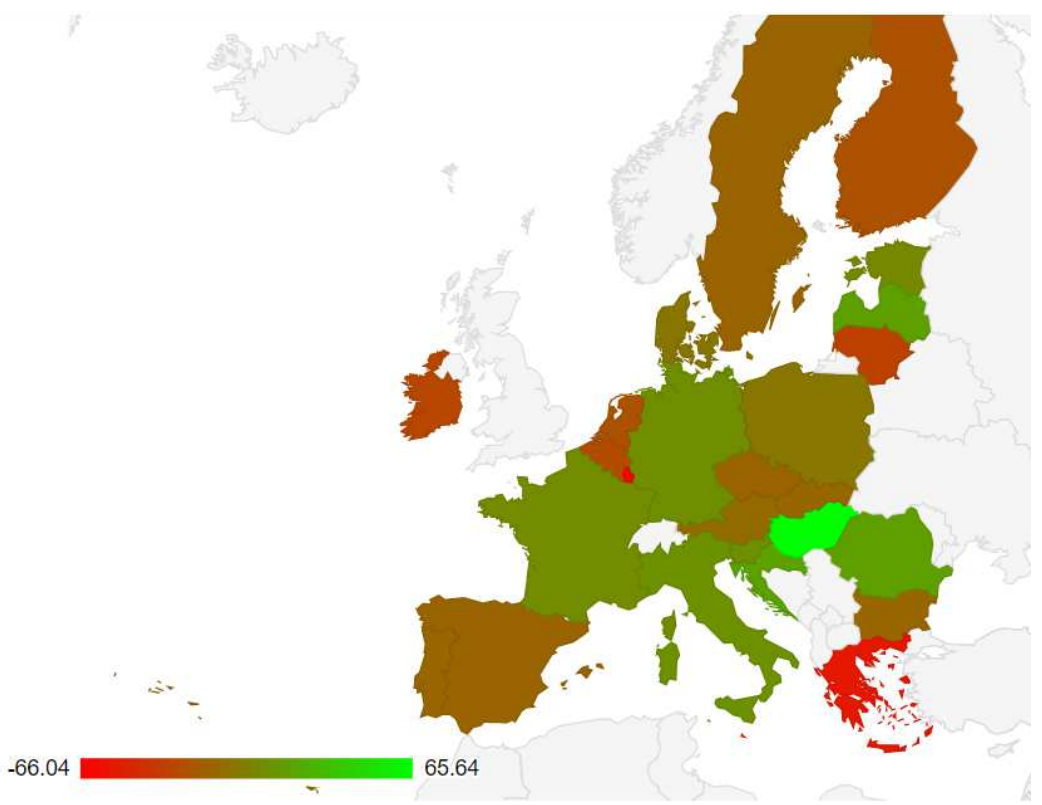

Source: Amadeus and Bankscope databases, own calculations. 
Furthermore, our baseline results are focusing on the post-Brexit landscape, therefore it is difficult to compare our results with previous extensive research, nevertheless that the research such as Cobham et al. (2017), Cobham and Loretz (2014), Fuest, Hemmelgarn and Ramb (2007) and many others are using micro data of firms located in the European Union, similar approach/conditions and the formula. Due to the fact that almost $44 \%$ of the current corporate tax base volume of all eligible companies is situated in the UK together with the highest cross-border losses and the highest number of eligible entities under the CCCTB, it is clear that Brexit significantly will change the amount of eligible entities, a composition of MNEs' groups, their consolidated values and redistribution of the corporate tax base according to the allocation factors of the formula. Our methodological innovations in contrast to earlier research are mainly based on the research of the mandatory entering the CCCTB system if the threshold of 750 mil. EUR is fulfilled (via CCCTB proposal in 2016); a change if the threshold is decreased to zero over a maximum period of 7 years (via the European Parliament, 2018); behavioural aspects including voluntary entering the CCCTB system; and finally Brexit.

Figure 1a

Distribution of the Tax Base among EU Member States (EUR 750 Million Thresholds) in the Post-Brexit Period

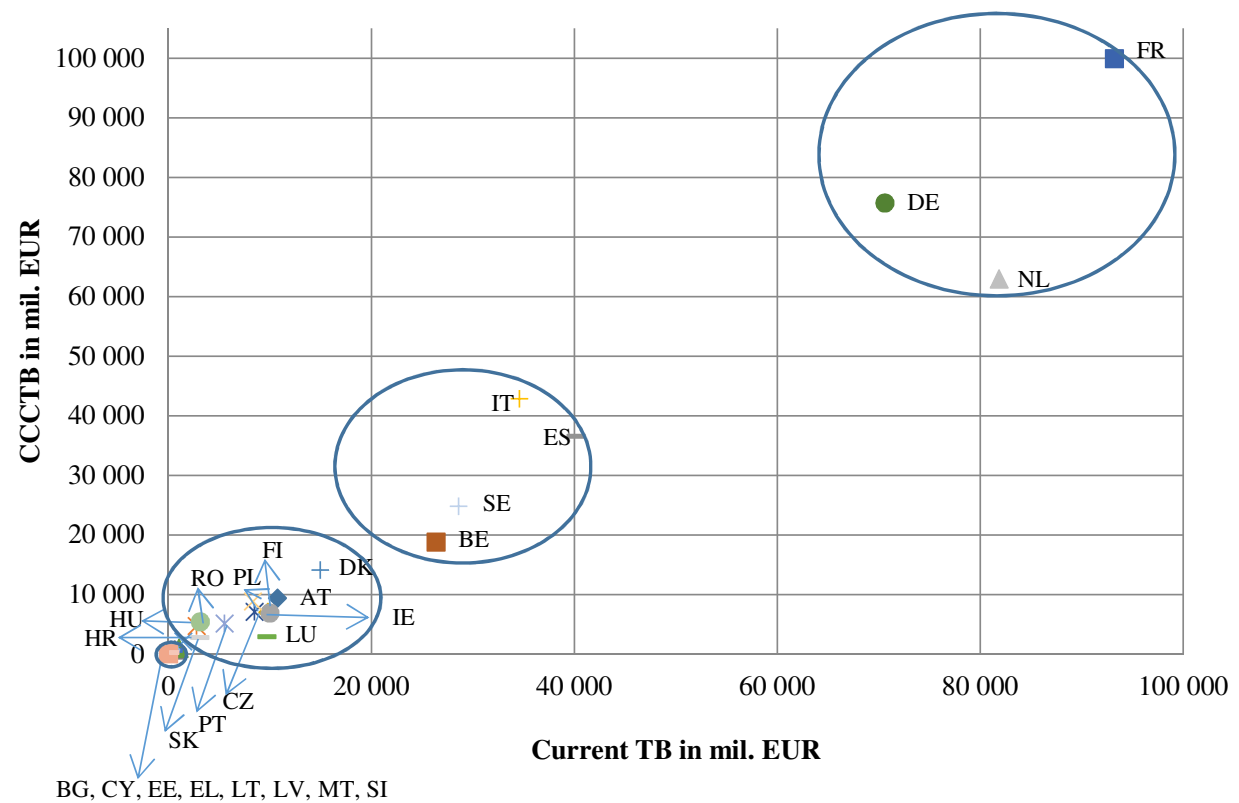

Source: Amadeus and Bankscope databases, own calculation. 
With regard to the distribution of the tax base between EU Member States, it is possible to distinguish four groups of countries. The first covers EU Member States that generate a tax base of up to EUR 1,000 million before and after the CCCTB system implementation with the EUR 750 million thresholds, such as Bulgaria, Cyprus, Estonia, Greece, Latvia, Lithuania, Malta and Slovenia. The second group covers EU Member States that generate a tax base of between EUR 1,000 million and 15,000 million before and after the CCCTB system implementation, such as Austria, Czech Republic, Denmark, Finland, Croatia, Hungary, Ireland, Luxemburg, Poland, Portugal, Romania and Slovak Republic. Those two groups can be considered small players with respect to the volume of the tax base but with high power, as they represent $74 \%$ of EU Member States. The remaining two groups can be considered large players because they generate tax bases that are several times larger in comparison with the previous groups. The third group generates a tax base of between EUR 18,000 million and 43,000 million, and the last group of between EUR 62,000 million and 100,000 million before and after the CCCTB system implementation; see Figure 1a.

Figure $1 b$

Distribution of the Tax Base among EU Member States (Zero Threshold) in the Post-Brexit Period

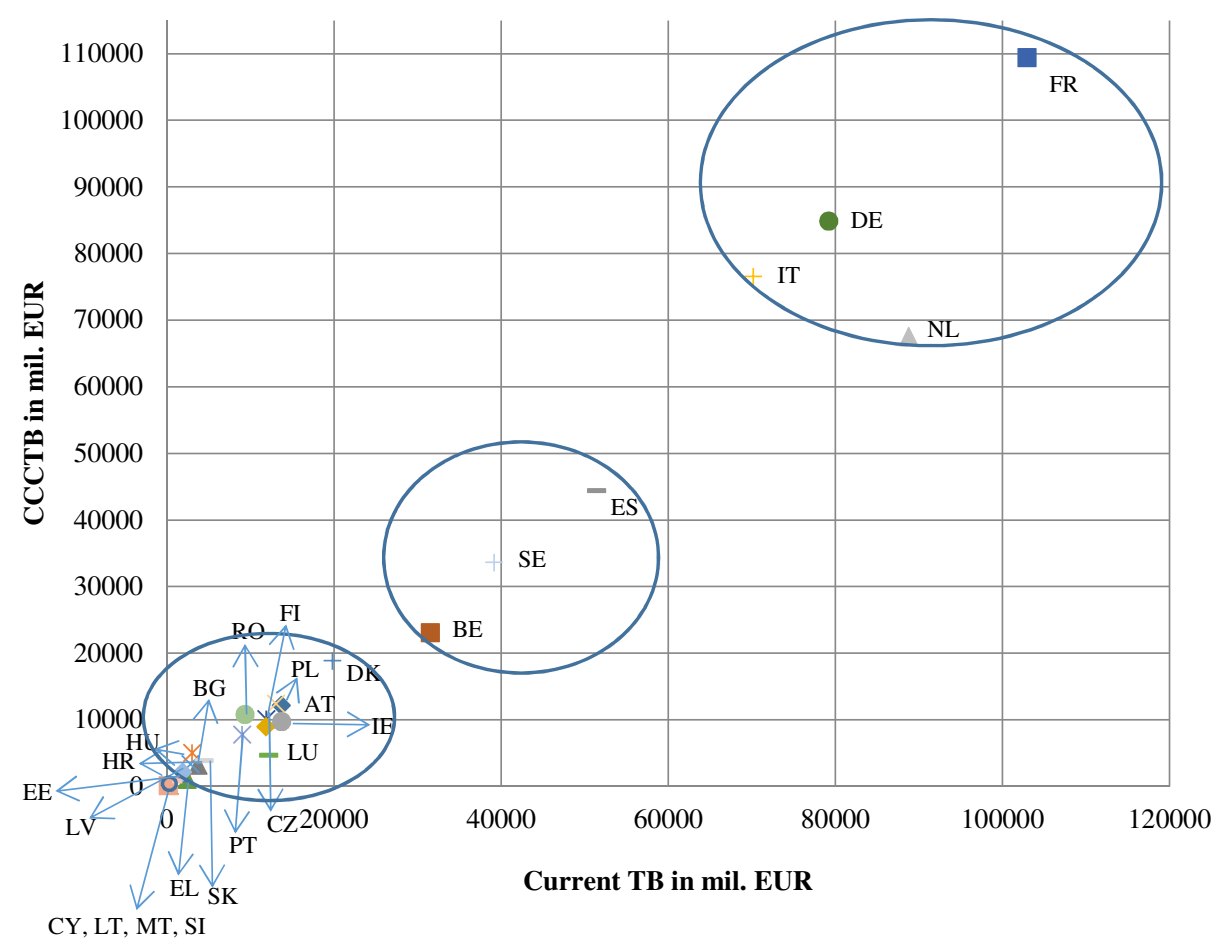

Source: Amadeus and Bankscope databases, own calculation. 
As shown in Figure 1b, the change in the threshold would not significantly change the groups. The first two groups would still cover 20 EU Member States and wield high power. Although the first group would now cover only Cyprus, Malta, Slovenia and Lithuania, the second group would generate a slightly higher tax base of up to EUR 20,000 million before and after the CCCTB system. In the case of the big players, 7 EU Member States remain, but Italy would transfer from the third to fourth group, which would generate a tax base of up to EUR 110,000 million. The largest players in the CCCTB system would still be France, Germany, the Netherlands and now Italy.

Behavioural effects - Eligible entities without the EUR 750 mil threshold-SMEs and large entities

The results mentioned in the previous chapter represent a static approach. The current chapter presents the results of applying the dynamic approach; i.e., we consider the voluntary entry of groups (SMEs and large entities) without EUR 750 million in consolidated turnover. The main incentive for these groups to enter the system is the overall decrease in the tax burden of the whole group. Our dataset covers 11,310 entities (8,561 SMEs and 2,749 large entities) that would probably opt for the CCCTB system and 404,715 entities (383,810 SMEs and 20,905 large entities) that would probably not opt for the CCCTB system (if only this main incentive is considered).

Sche me 2

Division of Entities Having the Possibility to Opt or Not Opt for the CCCTB (Resulting in a Lower/Higher Tax Liability) in the Post-Brexit Period (in \%)

Voluntary application

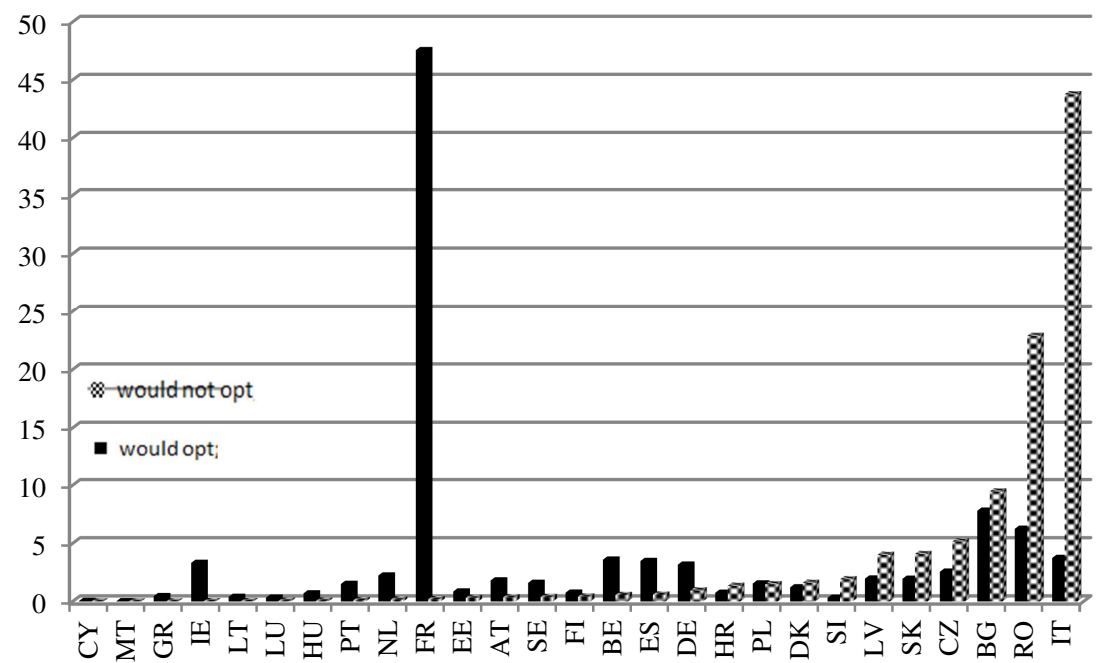

Source: Amadeus and Bankscope databases, own calculations. 
As seen in Scheme 2 below, the majority of the subsidiaries that would probably opt for the CCCTB are situated in France (48\%), Bulgaria (8\%) and Romania $(6 \%)$. The subsidiaries that would probably not opt for the CCCTB are based mainly in Italy (44\%), Romania (23\%) and Bulgaria (9\%). Moreover as it is obvious, the portion of entities that would (not) voluntary enter the CCCTB system is very small in the rest of countries. The results are interesting in the context of the current nominal tax rates, as Bulgaria represents the country with the lowest corporate tax rate, Romania belongs to the group of countries with lower corporate tax rates, and Italy, along with France, belongs to the group with the highest corporate tax rates in the EU.

Based on our research, only $2.72 \%$ of eligible entities (2.05\% of SMEs and $0.7 \%$ of large entities without the EUR 750 million thresholds) would enter into the CCCTB system if only the size of the overall tax liability of the group is considered. However, other benefits ${ }^{11}$ connected with the adoption of the CCCTB system should be taken into account. Therefore, to capture the dynamic effect and the changes in the behaviour of the entities, we further identify the range of possible impacts bounded by the minimum and maximum total effects. ${ }^{12}$

The minimum effect can be considered a more realistic variant because the overall lower tax burden of the group is a very strong incentive for voluntarily entering the CCCTB system. As seen in Tables 2 and 3 below, the CCCTB would increase by EUR 15,223 million (by 3.33\%) under the minimum effect. The highest volume of the CCCTB under the minimum effect would be reached in France (EUR 7.4 billion, a 6.93\% increase) and in Ireland (EUR 2.7 billion, a $28.53 \%$ increase). The maximum effect can be considered a rather unrealistic scenario, as it will never happen that all eligible entities without the threshold will enter the CCCTB system voluntarily. However, according to our research, the CCCTB would increase by EUR 112,581 million (by 20.29\%) in this case. The highest volume of the CCCTB under this maximum effect would be reached in Italy (EUR 34.5 billion, a $44.68 \%$ increase). Furthermore, it should be highlighted that there was no group of large entities identified as generating a lower tax liability under the CCCTB system (with voluntary entry) in the case of Cyprus and similarly for Malta in the case of SMEs. These results correspond to the current corporate taxation environment in these countries.

The change in behaviour of SMEs and large entities that are not obligated to enter the CCCTB system - a more realistic scenario in the form of the minimum effect - would have a small impact on the total volume of the CCCTB (only a $3.33 \%$ increase).

\footnotetext{
${ }^{11}$ Mentioned in the Data and Methodology - motivations section.

${ }^{12}$ Individual effects explained in the Data and Methodology section.
} 
However, the situation would be absolutely different across the EU Member States, as the range of the behavioural effect can be between $0.52 \%$ and $85.91 \%$; see Table 3.

T a b le 2

The Effects of Voluntary Entry into the CCCTB System in the Case of SMEs and Large Entities without the EUR 750 Million Threshold in the Post-Brexit Period (in Million EUR)

\begin{tabular}{|c|c|c|c|c|c|c|c|}
\hline \multirow{3}{*}{ Country } & \multicolumn{2}{|c|}{ Min effect } & \multirow{2}{*}{$\begin{array}{c}\text { CCCTB } \\
\text { including } \\
\text { min effect }\end{array}$} & \multicolumn{2}{|c|}{ Max effect } & \multirow{2}{*}{$\begin{array}{c}\text { CCCTB } \\
\text { including } \\
\text { max effect }\end{array}$} & \multirow{2}{*}{$\begin{array}{l}\text { CCCTB with } \\
\text { total effect } \\
\text { (min and } \\
\text { max) }\end{array}$} \\
\hline & SMEs & Large & & SMEs & Large & & \\
\hline & $\mathbf{A}$ & B & $\mathrm{C}$ & D & $\mathbf{E}$ & $\mathbf{F}$ & G \\
\hline FR & 1,572 & 5,867 & 107,317 & 504 & 4,022 & 104,403 & 111,843 \\
\hline $\mathrm{DE}$ & 102 & 292 & 76,079 & 3,014 & 6,965 & 85,664 & 86,058 \\
\hline NL & 114 & 682 & 63,757 & 1,650 & 4,122 & 68,732 & 69,529 \\
\hline IT & 67 & 257 & 43,164 & 13,783 & 20,815 & 77,438 & 77,762 \\
\hline ES & 42 & 287 & 36,881 & 392 & 7,543 & 44,486 & 44,816 \\
\hline SE & 24 & 550 & 25,324 & 2,847 & 6,157 & 33,754 & 34,328 \\
\hline $\mathrm{BE}$ & 96 & 117 & 18,966 & 1,666 & 3,078 & 23,497 & 23,710 \\
\hline DK & 64 & 87 & 14,204 & 2,063 & 4,058 & 20,174 & 20,325 \\
\hline $\mathrm{IE}$ & 1,714 & 1,036 & 9,639 & 1,138 & 431 & 8,458 & 11,208 \\
\hline AT & 52 & 144 & 9,624 & 476 & 2,224 & 12,129 & 12,324 \\
\hline PL & 30 & 296 & 9,172 & 1,067 & 2,347 & 12,260 & 12,585 \\
\hline $\mathrm{CZ}$ & 32 & 162 & 7,289 & 1,273 & 1,770 & 10,137 & 10,332 \\
\hline FI & 13 & 49 & 7,100 & 396 & 1,590 & 9,025 & 9,086 \\
\hline RO & 113 & 169 & 5,718 & 3,381 & 1,761 & 10,577 & 10,859 \\
\hline PT & 29 & 241 & 5,427 & 106 & 2,294 & 7,558 & 7,827 \\
\hline $\mathrm{HU}$ & 11 & 28 & 4,783 & 37 & 226 & 5,008 & 5,046 \\
\hline LU & 13 & 7 & 2,940 & 466 & 1,344 & 4,731 & 4,750 \\
\hline SK & 17 & 29 & 2,835 & 683 & 412 & 3,883 & 3,930 \\
\hline HR & 304 & 43 & 2,468 & 393 & 445 & 2,960 & 3,306 \\
\hline EL & 21 & 53 & 1,095 & 3 & 15 & 1,038 & 1,113 \\
\hline $\mathrm{EE}$ & 10 & 16 & 979 & 564 & 381 & 1,898 & 1,924 \\
\hline BG & 125 & 48 & 873 & 1,639 & 725 & 3,063 & 3,236 \\
\hline LV & 54 & 8 & 767 & 855 & 504 & 2,064 & 2,125 \\
\hline $\mathrm{LT}$ & 3 & 15 & 614 & 291 & 71 & 958 & 976 \\
\hline SI & 3 & 12 & 254 & 399 & 139 & 777 & 793 \\
\hline $\mathrm{CY}$ & 94 & 0 & 110 & 0 & 0 & 16 & 110 \\
\hline MT & 0 & 7 & 20 & 57 & 1 & 70 & 77 \\
\hline Total & 4,719 & 10,504 & 457,400 & 39,141 & 73,440 & 554,758 & 569,981 \\
\hline
\end{tabular}

Source: Amadeus and Bankscope databases, own calculations.

The highest share of the behavioural effect in the volume of the CCCTB would be produced in Cyprus, Malta and Ireland, and the lowest shares in Germany. Furthermore, this behavioural effect is able to change the negative effect of the CCCTB system in relation to the volume of the tax base, i.e., the CCCTB when the behavioural effect (minimum effect) is considered is higher than the current tax base. This situation is identified in the cases of Cyprus and Greece. Nevertheless, the behavioural effects should be short-term due to the suggested change in the mandatory threshold for entry into the CCCTB system from EUR 
750 million to zero over a maximum period of seven years (European Parliament, 2018). After that, all eligible entities would enter the mandatory CCCTB system, resulting in a volume of EUR 557.5 billion (see Table 1). This scenario almost corresponds with the one producing the maximum effect.

T a b l e 3

Decomposition of the Behavioural Effect under the CCCTB in the Case of SMEs and Large Entities without the EUR 750 Million Threshold in the Post-Brexit Period (in \%)

\begin{tabular}{|c|c|c|c|c|c|c|c|}
\hline \multirow[t]{2}{*}{ Country } & $\begin{array}{c}\text { Behavioural } \\
\text { effect - min } \\
\text { (portion) }\end{array}$ & $\begin{array}{c}\text { Behavioural } \\
\text { effect - max } \\
\text { (portion) }\end{array}$ & $\begin{array}{c}\text { Behavioural } \\
\text { effect - total } \\
\text { effect } \\
\text { (portion) }\end{array}$ & \multirow[t]{2}{*}{ Country } & $\begin{array}{c}\text { Behavioural } \\
\text { effect - min } \\
\text { (portion) }\end{array}$ & $\begin{array}{c}\text { Behavioural } \\
\text { effect - max } \\
\text { (portion) }\end{array}$ & $\begin{array}{c}\text { Behavioural } \\
\text { effect - total } \\
\text { effect } \\
\text { (portion) }\end{array}$ \\
\hline & $(\mathbf{A}+\mathbf{B}) / \mathrm{C}$ & $(\mathbf{D}+\mathbf{E}) / \mathbf{F}$ & $\begin{array}{c}(A+B+D \\
+E) / G\end{array}$ & & $(\mathrm{~A}+\mathrm{B}) / \mathrm{C}$ & $(\mathbf{D}+\mathbf{E}) / \mathbf{F}$ & $\begin{array}{c}(\mathbf{A}+\mathbf{B}+\mathbf{D} \\
+\mathbf{E}) / \mathbf{G}\end{array}$ \\
\hline $\mathrm{CY}$ & 85.91 & 0.00 & 85.91 & DK & 1.06 & 30.34 & 30.85 \\
\hline MT & 35.05 & 81.69 & 83.33 & PL & 3.55 & 27.84 & 29.71 \\
\hline BG & 19.89 & 77.17 & 78.40 & SK & 1.65 & 28.20 & 29.06 \\
\hline SI & 6.19 & 69.30 & 69.91 & SE & 2.27 & 26.67 & 27.90 \\
\hline LV & 8.05 & 65.81 & 66.81 & AT & 2.03 & 22.26 & 23.50 \\
\hline $\mathrm{EE}$ & 2.66 & 49.79 & 50.47 & FI & 0.87 & 22.01 & 22.53 \\
\hline RO & 4.93 & 48.61 & 49.94 & $\mathrm{BE}$ & 1.12 & 20.19 & 20.91 \\
\hline IT & 0.75 & 44.68 & 44.91 & ES & 0.89 & 17.84 & 18.44 \\
\hline LT & 2.93 & 37.77 & 38.92 & $\mathrm{DE}$ & 0.52 & 11.65 & 12.05 \\
\hline $\mathrm{LU}$ & 0.67 & 38.28 & 38.53 & FR & 6.93 & 4.33 & 10.70 \\
\hline IE & 28.53 & 18.55 & 38.53 & NL & 1.25 & 8.40 & 9.45 \\
\hline HR & 14.05 & 28.32 & 35.84 & EL & 6.81 & 1.68 & 8.28 \\
\hline PT & 4.96 & 31.76 & 34.11 & $\mathrm{HU}$ & 0.80 & 5.26 & 5.97 \\
\hline $\mathrm{CZ}$ & 2.67 & 30.01 & 31.33 & & & & \\
\hline Total & & & & & 3.33 & 20.29 & 22.42 \\
\hline
\end{tabular}

Source: Amadeus and Bankscope databases, own calculations.

If the results are compared with those in the studies by Nerudová and Solilová (2017a; 2019), it is obvious that the behavioural effect is significantly lower in the post-Brexit landscape. In view of these studies, this effect drops from EUR 131 billion to 15.2 billion in the minimum effect scenario and from EUR 197 billion to 112.5 billion in the maximum effect scenario. This change is caused mainly by the loss of more than one-third of eligible entities, namely, those situated in the United Kingdom. In regards to other studies focusing on the CCCTB, no comparisons can be made, as there are no studies covering post-Brexit conditions.

As regards to the Czech and Slovak Republic, both countries are not winners in that game. Brexit has negative impact on the tax-base sharing mechanism under the CCCTB as both countries would lose their previous winners' positions based on the research Nerudová and Solilová (2017b) and Nerudová and Solilová (2015b). In case of the mandatory application the Czech Republic and Slovak Republic would face by $17 \%$ and resp. by $10 \%$ lower corporate tax base. In case of all eligible entities enter the system they would face by $15 \%$ and resp. by $13 \%$ 
lower corporate tax base. With regard to the distribution of the tax base, both countries would stay at the second group not exceeding the tax base of EUR 15,000 million before and after the CCCTB system implementation. Furthermore, only 290 Czech entities (increasing the overall CCCTB by EUR 195 million) and 221 Slovak entities (increasing the overall CCCTB by EUR 47 million) would opt for the CCCTB voluntarily, and the impact of behavioural aspects on the overall CCCTB would be $31.31 \%$ in case the Czech Republic and $29.06 \%$ in case the Slovak Republic. The Czech government's position to the CCCTB proposal is still neutral; however, this statement had been done before Brexit, so we can expect its change in the future. The Slovak government's position to the CCCTB proposal is still negative.

The last point that should be mentioned is the tax yield from the CCCTB, which is affected by the application of the nominal corporate tax rate across the EU Member States. Corporate tax rates are not covered in the CCCTB directive proposal, i.e., each EU Member State has a right to decide the corporate tax rate used in its area. Therefore, it is assumed that EU Member States facing losses, such as the Czech Republic and Slovak Republic, in their tax base under the CCCTB would think about increasing their corporate tax rates. However, this situation will depend on tax competition among countries in the Internal market, and it is also being questioned. Furthermore, in the post-Brexit period, the tax yield from the CCCTB is very important, specifically in relation to the new taxbased own resources to finance the EU budget. Schratzenstaller (2019) highlights that it is important to increase national contributions as well as new own resources to fill the Brexit gap. The author, together with Nerudová et al. (2016), also considers the CCCTB as a suitable alternative for generating new resources. According to our research, the CCCTB without UK participation is still a suitable alternative because the decline of the tax base is not noticeable (by 5.34\%) in the post-Brexit period.

\section{Conclusions}

Our research proved that the tax-base sharing mechanism under the CCCTB without the contribution of the United Kingdom would be lower, as more than one-third of eligible entities together with more than $40 \%$ of the tax base are missing, but the overall change is not so serious. In comparison with the current tax base in the EU-27, the tax base under the CCCTB would decline by $5.34 \%$ (in the case of the EU-28, it would decline by $4.20 \%$ ) and would still be able to generate sufficient resources after Brexit. Furthermore, our research proved the same result as that in Nerudová and Solilová (2019) assessing the case in which 
the EU-28 changes the threshold for the mandatory entry of the CCCTB system, i.e., its decrease to zero does not mean a significant increase in the overall tax base. To capture the dynamic approach, we considered behavioural effects, which we consider to be short term as the threshold should quickly decline to zero. We identified the range of possible impacts bounded by the minimum and maximum effects, based on which the CССТВ may increase by between $3.33 \%$ and $22.42 \%$ depending on the type of behavioural effect. However, we highlight mainly the minimum behavioural effect, as this scenario is more realistic than that produced by the maximum effect.

In summary, based on the fiscal point of view, the CCCTB system would bring a decline of the tax base in the EU-27 in the post-Brexit landscape. However, the decrease in the tax base and consequently tax revenues under the CCCTB can be eliminated through the increase in the corporate tax rate, as this area remains open and is not covered in the CCCTB directive proposal. Furthermore, lowering the threshold does not imply a significant increase in the tax base under the CCCTB. The behavioural effects should be only short term, as would be the cross-border loss offsetting. Nevertheless, the CCCTB system offers many advantages, such as unitary taxation, lower compliance costs of taxation, fairer tax competition, and elimination of transfer pricing issues and profit shifting opportunities, which can compensate for the negative change of the overall tax base in the EU-27. Moreover, this kind of change in corporate taxation could mean a new challenge for the EU-27 in the post-Brexit period. The Internal market needs to be stronger and more effective, and more effective corporate taxation, without profit shifting opportunities, tax base erosion and the taxation of value added in the place where this value is not created, is one of the key areas for improvement in this regard. The partial improvements were done by the ATAD Directive and its implementation by the EU Member states. Currently the European Commission focuses on the Package for fair and simple taxation and the Action Plan for Business Taxation for the 21st century. Whether policymakers give the CCCTB system a new chance in the future, we will see.

\section{References}

ANDERSSON, K. (2007): An Optional Common Consolidated Corporate Tax Base in the European Union. In: ANDERSSON, K. EBERHARTINGER, E. and OXELHEIM, L. (eds): National Tax Policy in Europe - To Be or not to Be? Heidelberg: Springer, pp. 85 - 119. Available at: <https://doi.org/10.1007/978-3-540-70711-0>.

BARENFELD, J. (2007): A Common Consolidated Corporate Tax Base in the European Union A Beauty or a Beast in the Quest for Simplicity? Bull Int Tax, 61, No. 7, pp. $258-271$.

BETTENDORF, L. - DEVEREX, M. P. - VAN DER HORST, A. - LORETZ, S. - DE MOOIJ, R. (2009): Corporate Tax Harmonization in the EU. [CPB Discussion Paper, No. 133.] Oxford: Oxford University. 
BROCHNER, J. - JENSEN, J. - SVENSSON, P. - SORENSEN, P. B. (2007): The Dilemmas of Tax Coordination in the Enlarged European Union. [CESifo Economic Studies 53.] Oxford: Institute for Economic Research.

BOULANGER, P. - PHILIPPIDIS, G. (2015): The EU Budget Battle: Assessing the Trade and Welfare Impacts of CAP Budgetary Reform. Food Policy, 51, No. 2, pp. 119 - 130. Available at: <https://doi.org/10.1016/j.foodpol.2015.01.004>.

CLINE, R. - NEUBIG, T. - PHILLIPS, A. - SANGER, CH. - WALSH, A. (2010): Study on the Economic and Budgetary Impact of the Introduction of a Common Consolidated Corporate Tax Base in the European Union. Ernst \& Young LLP.

COBHAM, A. - LORETZ, S. (2014): International Distribution of the Corporate Tax Base: Implications of Different Apportionment Factors under Unitary Taxation. [Working Paper, No. 27.] Brighton: International Centre for Tax and Development.

COBHAM, A. - JANSKÝ, P. - JONES, CH. - TEMOURI, Y. (2017): Assessing the Impact of the C(C)CTB: European Tax Base Shifts under a Range of Policy Scenarios. [A Study for the European Parliament.] European United Left, Nordic Green Left, European Parliamentary Group.

DAHLE, C. - BÄUMER, M. (2009): Cross-Border Group-taxation and Loss-offset in the EU - An Analysis for CCCTB (Common Consolidated Corporate Tax Base) and ETAS (European Tax Allocation System). [Arqus Discussion Paper, No. 66.] Berlin: Arbeitskreis Quantitative Steuerlehre.

DE WILDE, M. F. (2017): Tax Competition within the European Union Revisited - Is the Relaunched CCCTB a Solution? Available at: <https://ssrn.com/abstract=3040702> or <http://dx.doi.org/10.2139/ssrn.3040702>. [July 1, 2017.]

DEVEREUX, M. P. - LORETZ, S. (2008): Increased Efficiency through Consolidation and Formula Apportionment in the European Union? [Working Paper, No. 12.] Oxford: Centre for Business Taxation.

DOMONKOS, T. - DOMONKOS, S. - DOLINAJCOVA, M. - GRISAKOVA, N. (2013): The Effect of the Formula Apportionment of the Common Consolidated Corporate Tax Base on Tax Revenue in the Slovak Republic. Ekonomický časopis/Journal of Economics, 61, No. 5, pp. 453 - 467.

EBERHARTINGER, E. - PETUTSCHNIG, M. (2014): CCCTB - The Employment Factor Game. [International Taxation Research Paper Series, No. 2014 - 01.] Vienna: WU.

EICHFELDER, S. - HECHTNER, F. - HUNDSDOERFER, J. (2018): Formula Apportionment: Factor Allocation and Tax Avoidance. Eur Account Rev, 27, No. 4, pp. 649 - 681. DOI: $10.1080 / 09638180.2017 .1364165$.

EUROPEAN COMMISSION (2011): Proposal for a Council Directive on a Common Consolidated Corporate Tax Base. [Document, No. COM(2011) 121/4.] Brussels: European Commission.

EUROPEAN COMMISSION (2016a): Proposal for a Council Directive on a Common Corporate Tax Base. [Document, No. COM(2016) 685 final.] Brussels: European Commission.

EUROPEAN COMMISSION (2016b): Proposal for a Council Directive on a Common Corporate Tax Base. [Document, No. COM(2016) 683 final.] Brussels: European Commission.

EUROPEAN PARLIAMENT (2018): REPORT on the Proposal for a Council Directive on a Common Consolidated Corporate Tax Base (CCCTB) (COM(2016)0683 - C8-0471/2016 - 2016/0336 (CNS)). Available at: <http://www.europarl.europa.eu/sides/getDoc.do?pubRef=-//EP//NONSGML +REPORT+A8-2018-0051+0+DOC+PDF+V0//EN>.

FELBERMAYER, G. - FUEST, C. - GRÖSCHL, J. K. - STÖHLKER, D. (2017): Economic Effects of Brexit on the European Economy. [EconPol Policy Reports 4.] Leibniz: Ifo Institute, Institute for Economic Research at the University of Munich.

FUEST, C. - HEMMELGARN, T. - RAMB, F. (2007): How Would the Introduction of an EUWide Formula Apportionment Affect the Distribution and Size of the Corporate Tax Base? An Analysis Based on German Multinationals. International Tax and Public Finance, 14, No. 5, pp. 605 - 626. DOI: 10.1007/s10797-006-9008-6.

HENTZE, T. (2019): The Challenge of Moving to a Common Consolidated Corporate Tax Base in the EU. [IW-Report, No. 2/2019.] Köln: Institut der deutschen Wirtschaft (IW). Available at: <https://www.econstor.eu/handle/10419/191535>. 
HINES, J. R. (2008): Income Misattribution under Formula Apportionment. European Economic Review, 54, No. 1, pp. $108-120$.

HM GOVERNMENT (2016): HM Treasury Analysis: The Immediate Economic Impact of Leaving the EU. [Cm 9292.] Available at:

<https://assets.publishing.service.gov.uk/government/uploads/system/uploads/attachment_data/file/ 524967/hm_treasury_analysis_the_immediate_economic_impact_of_leaving_the_eu_web.pdf >

HUNDSDOERFER, J. - WAGNER, J. (2020): How Accurately Does the CCCTB Apportionment Formula Allocate Profits? An Evaluation of the European Commission Proposal. J Bus Econ, Springer, 90, No. 4, pp. 495 - 536. Available at: 〈https://doi.org/10.1007/s11573-019-00962-1>.

HULYA, C. - HODŽIĆ, S. (2017): The Impact of Corporate Income Tax on R\&D of Multinational Entities: An Impact Analysis of Separate Taxation and CCCTB. European Financial and Accounting Journal, 12, No. 3, pp. $17-32$.

KESER, C. - KIMPEL, G. - OESTREICHER, A. (2016): Would a CCCTB Mitigate Profit Shifting? CIRANO, Scientific Series. Montréal, June 2016. Available at: <https://mphxxx.cirano.qc.ca/files/publications/2016s-29.pdf>.

KIESEWETTER, D. - STEIGENBERGER, T. - STIER, M. (2018): Can Formula Apportionment Really Prevent Multinational Enterprises from Profit Shifting? The Role of Asset Valuation, Intragroup Debt, and Leases. J Bus Econ, Springer, 88, No. 9, pp. 1029 - 1060. Available at: $<$ https://doi.org/10.1007/s11573-018-0891-y>.

KRCHNIVÁ, K. - NERUDOVÁ, D. (2015): The Influence of Allocation Formula on Generation of Profit in Different Economy Sectors. Acta Universitatis Agriculturae et Silviculturae Mendelianae Brunensis, 63, No. 6, pp. $1961-1967$.

MARTINI, J. T. - NIEMANN, R. - SIMONS, D. (2012): Transfer Pricing or Formula Apportionment? Tax-in-Duced Distortions of Multinationals' Investment and Production Decisions. Contemp Acc Res, 29, No. 4, pp. 1060 - 1086. Available at: <https://doi.org/10.1111/j.1911-3846.2012.01140.x>.

MINTZ, J. (2008): Europe Slowly Lurches to a Common Consolidated Corporate Tax Base: Issues at Stake. In: LANG, M. et al. (eds): A Common Consolidated Corporate Tax Base for Europe. Alemanha: Springer, pp. $128-138$.

NERUDOVÁ, D. - SOLILOVÁ, V. (2019): The Impact of the Introduction of a CCCTB in the EU. Intereconomics, 54, No. 3, pp. 160 - 165. Available at:

$<$ https://link.springer.com/article/10.1007\%2Fs10272-019-0815-2>; <https://doi.org/10.1007/s10272-019-0815-2>.

NERUDOVÁ, D. - SOLILOVÁ, V. (2017a): Report On Behavioural Model for Measurement of the Impacts of Tax Sharing Mechanism under C(C)CTB. [FairTax Working Paper, No. 12.] Umeå: Umeå universitet.

NERUDOVÁ, D. - SOLILOVÁ, V. (2017b): Common Consolidated Corporate Tax Base System Re-launching: Simulation of the Impact on the Slovak Budget Revenues. Ekonomický časopis/ Journal of Economics, 65, No. 6, pp. $559-578$.

NERUDOVÁ, D. - SOLILOVÁ, V. (2015a): The Impact of the CCCTB Introduction on the Distribution of the Group Tax Bases across the EU: The Study for the Czech Republic. Prague Economics Papers, 24, No. 6, pp. $621-637$.

NERUDOVÁ, D. - SOLILOVÁ, V. (2015b): Kvantifikace Dopadů zavedení společného konsolidovaného základu daně v Evropské Unii do celkového základu daně korporací vykazovaného v České republice. Politická ekonomie, 63, No. 4, pp. 322 - 339.

NERUDOVÁ, D. - SOLILOVÁ, V. - DOBRANSCHI, M. (2016): Sustainability Oriented Future EU-funding: The Case of a C(C)CTB. [FairTax Working Paper, No. 4.] Umeå: Umeå universitet.

NIELSEN, S. B. - RAIMONDOS-MØLLER, P. - SCHJELDERUP, G. (2010): Company Taxation and Tax Spillovers: Separate Accounting versus Formula Apportionment. Eur Econ Rev, 54, No. 1, pp. 121 - 132. Available at: 〈https://doi.org/10.1111/ecaf.12234>.

OESTREICHER, A. - KOCH, R. (2011): The Revenue Consequences of Using a Common Consolidated Corporate Tax Base to Determine Taxable Income in the EU Member States. Finanz Archiv, 67, No. 1, pp. 64 - 102. Available at: <https://www.jstor.org/stable/41303579>. 
OESTREICHER, A. - KESER, C. - KIMPEL, G. (2013): The CCCTB Option - An Experimental Study. [WP 14/04.] Oxford: University Centre for Business Taxation.

ORTMANN, R. - SURETH-SLOANE, C. (2016): Can the CCCTB Alleviate Tax Discrimination against Loss-making European Multinational Groups? Journal of Business Economics, 86, No. 5, pp. 441 - 475. Available at: 〈https://doi.org/10.1007/s11573-015-0780-6>.

OTTAVIANO, G. - PESSOA, J. P. - SAMPSON, T. - VAN REENEN, J. - VAITILINGA, R. (2015): Brexit or Fixit? The Trade and Welfare Effects of Leaving the European Union. CEP Policy Analysis. Available at:

<http://eprints.lse.ac.uk/57958/1/_lse.ac.uk_storage_LIBRARY_Secondary_libfile_shared_re pository_Content_Centre_for_Economic_Performance_Policy\%20Analysis_pa016.pdf $>$.

PIRVU, D. - BANICA, L. - HAGIU, A. (2011): Implications of the Introduction of the Common Consolidated Corporate Tax Base for Tax Revenues in Romania. Financial Theory and Practice, 35, No. 2, pp. $197-215$.

RIEDEL, N. - RUNKEL, M. (2007): Company Tax Reform with a Water's Edge. Journal of Public Economics, 91, No. 7 - 8, pp. 1533 - 1554.

RÖDER, E. (2012): Proposal for an Enhanced CCTB as Alternative to a CCCTB with Formulary Apportionment. [Working Paper of the Max Planck Institute for Tax Law and Public Finance, No. 2012-01.] World Tax Journal, 4, No. 2, pp. 125 - 150, Available at: $<$ https://ssrn.com/abstract=2012640> or <http://dx.doi.org/10.2139/ssrn.2012640>. [February 28, 2012.]

ROGGEMAN, A. - VERLEYEN, I. - VAN CAUWENBERGE, P. - COPPENS, C. (2012): An Empirical Investigation into the Design of an EU Apportionment Formula Related to Profit Generating Factors. Transformations in Business \& Economics, 11, No. 27, pp. 36 - 56.

SCERRI, A. (2009): The Common Consolidated Corporate Tax Base (CCCTB): Should Malta Adopt It? [A Dissertation in the Faculty of Economics, Management and Accountancy.] Available at: 〈https://www.um.edu.mt/library/oar/bitstream/123456789/2901/1/09BACC064.pdf〉.

SCHRATZENSTALLER, M. - KRENEK, A. (2019): Tax-based Own Resources to Finance the EU Budget: Potential Revenues, Summary Evaluation from a Sustainability Perspective, and Implementation Aspects. [FairTax Working Paper, No. 25.] Umeå: Umeå universitet.

SCHRATZENSTALLER, M. (2019): Brexit and the EU Budget. In: ZAMPARINI, L. and VILLANILUBELLI, U. (eds): Features and Challenges of the EU Budget A Multidisciplinary Analysis. Cheltenham: Edward Elgar Publishing Ltd, pp. 180 - 204. ISBN 9781788971911. Available at: <https://doi.org/10.4337/9781788971928.00018>.

SKJERPE, I. (2012): The CCCTB Proposal and Norway Profit Shifting, Investments and Implications for Norwegian Government Behaviour. [Master Thesis Cand.Merc.] Stavanger: International Business, Department of International Economy and Management, Copenhagen Business School. Available at: <https://research-api.cbs.dk/ws/portalfiles/portal/58430249/ingeborg_skjerpe.pdf>.

SAMPAIO CÂNDIDO DA, S. A. (2016): The Introduction of CCCTB - Common Consolidated Corporate Tax Base in Portugal. [Masters Dissertation.] Lisbon: Universidade de Lisboa. Instituto Superior de Economia e Gestão.

SOLILOVÁ, V. - NERUDOVÁ, D. (2018): Výnosový potenciál společného konsolidovaného korporátního základu daně v Evropské unii. Politická ekonomie, 66, No. 1, pp. 78 - 98.

VALENDUC, Ch. (2019): Corporate Income Tax in the EU, the Common Consolidated Corporate Tax Base (CCCTB) and Beyond: Is it the Right Way to Go? [ETUI Research Paper - Working Paper 2018.06.] Available at: <https://ssrn.com/abstract $=3316120>$ or $<$ http://dx.doi.org/10.2139/ssrn.3316120>. [January 15, 2019.]

VAN DER HORST, A. - BETTENDORF, L. - ROJAS-ROMAGOSA, H. (2007): Will Corporate Tax Consolidation Improve Efficiency in the EU? [CPB Documents, No. 141.] Amsterdam: Netherlands Bureau for Economic Policy Analysis. 